\title{
Physical Exercise for Individuals With Spinal Cord Injury: Systematic Review Based on the International Classification of Functioning, Disability, and Health
}

\author{
Roberta Gaspar, Natalia Padula, Tatiana B. Freitas, João P.J. de Oliveira, \\ and Camila Torriani-Pasin
}

\begin{abstract}
Introduction: Considering the reduction of physical activity performed daily in people with spinal cord injury, it is necessary to analyze the interventions based on physical exercises in order to provide recommendations based on evidence. Objectives: To review and evaluate the literature on physical exercise interventions for individuals with SCI, based on the International Classification of Functioning, Disability and Health, as well as physiological parameters for exercise prescription. Method: A systematic review of the literature produced from August 2016 to February 2017 within the PubMed, Embase, Cochrane Library, and MEDLINE databases. Results: Two independent examiners conducted a search in which 223 articles were initially found. A third evaluator verified possible divergences and generated a final list of 25 articles that strictly met the inclusion criteria, 5 of which investigated the effects of aerobic exercise, 2 of resistance training, 2 of balance training, 12 of gait training, and 4 evaluating the combined effect of 2 or more forms of training. Conclusion: Considering studies classified as of high and moderate quality of evidence, positive effects were observed in the domains of structures and functions, in aerobic, resistance training and combined exercises, and in some studies with gait training. In the domain of activities and participation, positive effects were observed in the studies with gait training, balance training, and combined interventions.
\end{abstract}

Keywords: paraplegia, tetraplegia, resistance, balance, gait, training, aerobic

Spinal cord injury (SCI) is a devastating health condition, which is associated with permanent disability and reduction in life expectancy. ${ }^{1}$ Global data state a high annual incidence between 12.1 and 57.8 per million inhabitants, the same with prevalence that ranges between 236 and 1009 per million inhabitants. ${ }^{2}$

Spinal cord injury results in sensory, motor, and autonomic dysfunction. Consequently, it affects the physical, psychological, and social well-being of suffering individuals. ${ }^{3}$ In addition, SCI causes a lack of control of somatic and autonomic systems, resulting in a reduction in physical activity and cardiovascular response to exercise. ${ }^{4}$

The reduction in physical activity level and the systemic impairments after injury encourage sedentarism in subjects with SCI. ${ }^{5,6}$ Among the most significant consequences of reduction in physical activity level are musculoskeletal changes - that is, muscular atrophy, osteopenia/osteoporosis, hypertonia, and restrictions of joint mobility — body composition changes, and metabolic and cardiorespiratory disorders, which increase the risk of comorbidity secondary to injury. ${ }^{7-9}$

Decline in muscle strength, endurance, and functional capacity are the main health concerns among SCI individuals and have been linked to decreased quality of life in those with SCI. ${ }^{10}$ According to Dunlop et al, ${ }^{11}$ sedentary behavior and inactivity are the main risk factors associated with the development of metabolic and

Gaspar is with the Acreditando Center of Neuromotor Recovery, Health and WellBeing, São Paulo, Brazil. Gaspar, Padula, Freitas, de Oliveira, and Torriani-Pasin are with the School of Physical Education and Sport (EEFE), University of São Paulo (USP), São Paulo, Brazil. Padula is also with the Acreditando Center of Neuromotor Recovery, Health and Wellness, São Paulo, Brazil. Padula (nataliapadula@yahoo. com.br) is corresponding author. cardiovascular disorders and have been associated with reduction in muscle strength and reduced aerobic capacity.

Therefore, it is necessary to offer therapeutic activities, exercise programs, sports modalities, and adequate recreational activities to individuals suffering from SCI in order to promote their participation in physical exercise programs. ${ }^{12,13}$ However, there is a lack of scientific literature providing information on how to develop appropriate exercise training programs for SCI individuals based on evidence.

Given the diversity of clinical pictures presented after SCI and the different functional impairments associated, it is necessary to analyze interventions based on available physical exercises in order to provide evidence-based recommendations. ${ }^{14-16}$

The ability to describe, classify, and code information and measures on a wide range of health issues requires common structures and language. The International Classification of Functioning, Disability and Health (ICF) developed by the World Health Organization constitutes a useful framework for understanding the complex interaction between the various factors that may affect the performance of activities and participation, including barriers for community-based skills after SCI. ${ }^{17}$

Therefore, the present study intends to review and critically appraise the literature regarding the physical exercises intervention to subjects with SCI.

The data analysis and critical appraisal were conducted based on the ICF framework as well as physiological parameters for exercise prescription.

\section{Method}

A systematic review of the literature was conducted from August 2016 to February 2017. 


\section{Eligibility Criteria}

The review of the literature was performed within the PubMed, Embase, Cochrane Library, and MEDLINE databases.

The following terms were used: spinal cord injury AND aerobic exercise, spinal cord injury AND resistance training, spinal cord injury AND balance training, and spinal cord injury AND gait training. Only research on human beings, published in English, which had the keywords in the titles and/or abstracts were considered in the search.

In this review, the studies included were randomized clinical trials, controlled clinical trials, observational studies, and case studies published by February 2016. Excluded studies were studies, which did not specifically investigate physical exercise and its effects, those that did not use data collected from subjects after SCI, and those in which the full version of the article was not found within database or by contacting the author.

The selected articles were categorized according to the type of intervention: aerobic exercise, resistance training, balance training, and gait training. Furthermore, we considered the category "combined exercises," which presented more than one associated intervention.

Studies are presented following these descriptions: characteristics of the sample, purpose of the study, intervention time, intervention parameters, adherence to FITT (frequency, intensity, type, and time) principles, and effects. The components of exercise prescription are frequency, intensity, time, and type (or modality), which are often referred to as the FITT principle. The components of the FITT principle constitute the exercise dose or quantity needed to improve health similar to a pharmacologic intervention. ${ }^{18}$ The ICF framework was also considered for data analysis, selecting the body structure and function, activity and participation level.

\section{Data Collection and Analysis}

Two independent examiners conducted the search. After this survey, a third evaluator verified possible divergences and generated a final list.

\section{Assessment of Methodological Quality of Studies and Outcomes Classification}

The methodological quality of the articles was evaluated through the GRADE (grading of recommendations, assessment, development, and evaluation) system. The GRADE system was used as substitute for the Physiotherapy Evidence Database (PEDro) scale, because PEDro only allows the assessment of randomized clinical trials, and this review included other scientific study designs.

The GRADE provides a quality rating system for evidence in systematic reviews and guidelines and for grading strength of recommendations. The system is designed for reviews and guidelines that examine alternatives of strategic management or interventions, which may include no intervention or the best current practice.

In the GRADE approach, the quality of evidence is classified into 4 levels: high, moderate, low, and very low. Randomized controlled trials begin as high-quality evidence and observational studies as low-quality evidence and rise or fall in ranking depending on estimates of intervention effects. ${ }^{19}$

After initial classification, methodological limitations (risk of bias), inconsistency, indirect evidence, inaccuracy, and publication bias may lower the quality of evidence. Additionally, if the level of evidence has not been rated down due to the above factors, the evidence from observational studies may be rated up based on 3 factors: effect of high-magnitude, dose-response gradient, and factors of residual confounding, which increase confidence in estimates. ${ }^{19}$

\section{Results}

After the search, 223 articles were found. Of this total, 113 articles were excluded because they were duplicates, and another 15 articles were excluded due to lack of access to the full text, even after contacting the author. Of the 95 remaining articles, 70 were excluded because they did not present the keywords in the titles or abstracts or did not specifically address the effects of physical exercises. Finally, 25 articles were included, 5 of which investigated the effects of aerobic exercise, 2 of resistance training, 2 of balance training, 12 of gait training, and another 4 evaluating the combined effect of 2 or more forms of training (Figure 1).

Of the 25 selected articles, 7 were classified as high-quality evidence, 6 as moderate, 11 as low, and only 1 as very low. In addition to the methodological classification, the selected studies were classified according to the outcomes within the domains of ICF. Table 1 presents an overview of selected and classified studies according to the quality of evidence, categorizing the outcomes according to the ICF aspects.

Five selected studies were categorized as aerobic exercise; among these, the studies classified as moderate were those with the best quality of evidence. The study populations were heterogeneous in terms of the level of injury, but homogeneous in terms of Frankel's classification, given that all the subjects had injuries classified as ASIA A. The times and parameters of activity were varied, as were the presented outcomes, which are illustrated in Table 2.

Only 2 studies presented resistance training interventions, of which one was classified as high and the other as low quality as well as aerobic exercise studies were heterogeneous in relation to intervention parameters; however, both groups of subjects suffered from incomplete SCI (tetraplegia and paraplegia) classified as ASIA C and D (Table 3).

Of the selected studies, 2 presented balance training interventions, of which one was classified as high and the other as low quality, similar to the findings for resistance training. These studies presented heterogeneous samples in terms of functional classification of SCI. In both studies, participants performed balance training 3 times a week, with study times varying in duration from 4 to 6 weeks. Different tests were used to evaluate improvement in balance (Table 4).

Of the 25 selected studies, 12 studies used gait training intervention. Of these, 6 were classified as low, 2 as moderate, and 4 as high quality. The studies were homogenous in terms of the level of injury (quadriplegia and paraplegia) and the functional classification of SCI as incomplete, with the exception of one study with low-quality evidence that used subjects with injuries classified as "complete" and "incomplete" in their sample. The studies were heterogeneous concerning the parameters and equipment used; 4 studies used robotic devices, and 4 studies used functional electrical stimulation (FES). The main outcomes mentioned were gait parameters, such as speed and resistance (Table 5).

Table 6 presents the 4 studies that used a combination of interventions in their methodology. These studies have investigated the effects of aerobic exercise and resistance training. These studies 


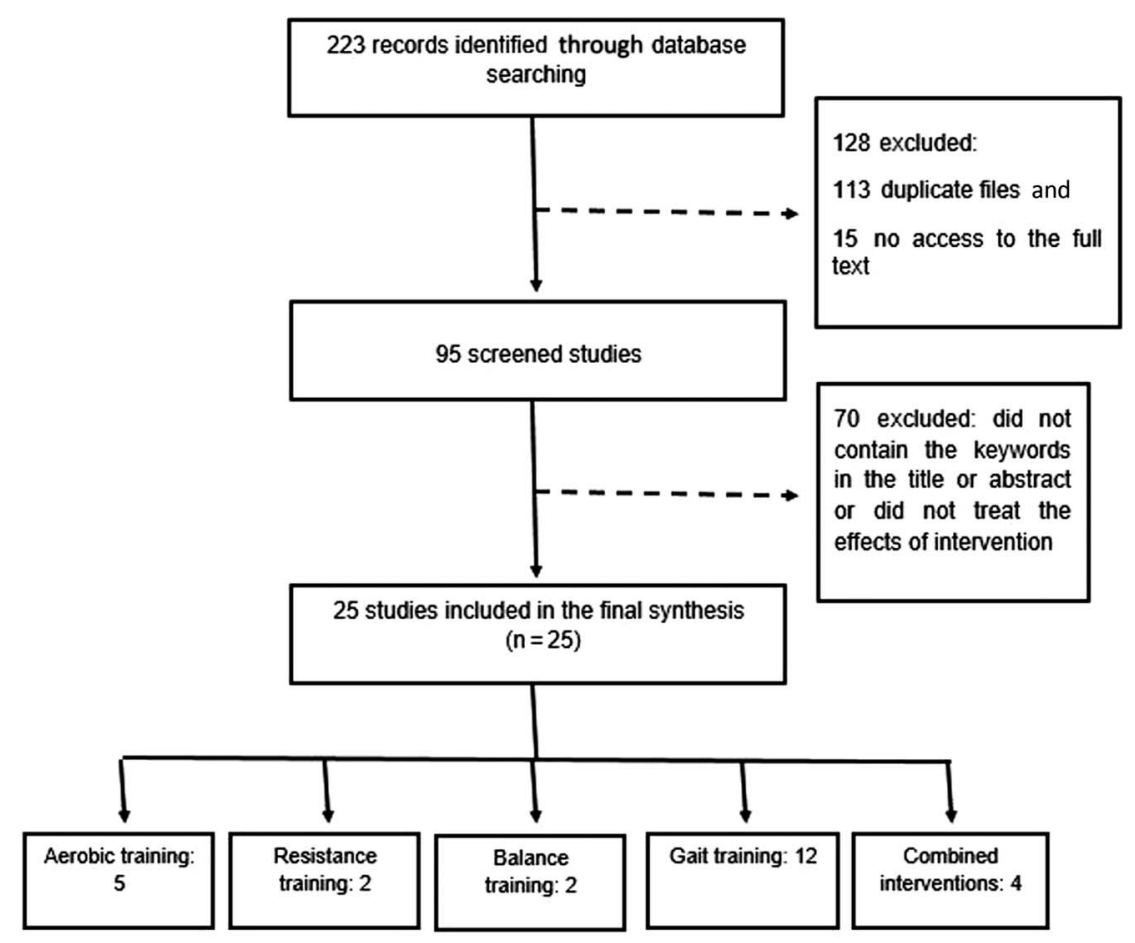

Figure 1 - Flowchart of the study selection procedure.

were heterogeneous in terms of activity parameters. Of the 4 studies, 1 was classified as low, 2 as moderate, and 1 as high quality.

\section{Discussion}

This review included 25 studies that investigated the effects of different physical exercise programs for SCI subjects. Of the 25 studies, 5 presented aerobic exercise intervention, 2 presented resistance training, 2 used balance training, 11 presented gait training, and 5 presented 2 or more types of exercise within the same intervention.

Most authors have investigated outcomes related to the components of structures and body functions. Some have investigated outcomes in terms of parameters such as gait performance (tests of 10-m walk, 6-min walk, Timed Up and Go, and Walking Index for SCI) and balance tests (Berg Scale) and a few in terms of effects on quality of life and depression. There is a lack of studies investigating the effects of exercise on the SCI population, especially on quality of life as the primary outcome.

\section{Characteristics of Subjects}

The participants included in the studies were heterogeneous in relation to age, type/level of injury, and time after injury. The studies included young and elderly, individuals with tetraplegia and paraplegia with complete and incomplete injuries and different degrees of impairment, based on the ASIA Impairment Scale.

For example, for the authors who investigated the effects of aerobic exercise, the population was mostly composed of individuals with paraplegia, ${ }^{21,22,24}$ and only one study involving aerobic training had a sample composed only of subjects with tetraplegia. ${ }^{20}$ This preference for individuals with lower level injuries is probably due to the difficulties in developing aerobic exercise programs for individuals with tetraplegia. There are barriers to selection of equipment and/or ergometers adapted to higher-level injuries. In addition, the use of ergometers for upper limbs is not always possible for this population. There are other possible reasons, such as reports of these individuals experiencing muscle fatigue prior to cardiorespiratory fatigue and impairments in the autonomic nervous system that make it difficult to control the heart rate. For individuals with this impairment, the main measure of intensity used was the subjective perception of effort based on the original Borg Scale (6-20) and the modified Borg Scale (0-10), as described in the study of Paulson et al ${ }^{45}$ which showed a relationship between subjective perception of exertion and $\mathrm{VO}_{2}$ in athletes with cervical injuries.

The studies evaluating aerobic exercise presented a wide variety of FITT principles. ${ }^{18}$ The most common type was a cycle ergometer for the upper limbs ${ }^{22-24}$ and an ergometric bicycle assisted by functional stimulation. ${ }^{23}$ The intensity was prescribed based on percentage of maximal oxygen uptake $\left(60 \% \mathrm{VO}_{2} \mathrm{max}\right)^{22}$ and percentage of heart rate reserve (50\%-80\% HRR). ${ }^{19,20,23}$ Regarding the duration of the session, the range was from 30 to 45 minutes, and the general frequency of 3 times a week. ${ }^{20,21,23,24}$

The 2 studies that evaluated resistance training interventions $\mathrm{s}^{25,26}$ were directed to segments affected by injury. Therefore, only individuals with incomplete injuries (ASIA C and D) who had voluntary muscle activity were selected. The presented results do not allow generalizing results to people with complete SCI, and may be considered a limitation for this review.

In the gait training interventions, there is a predominance of studies with incomplete SCI patients, given the greater potential for functional gait recovery for these individuals. In addition, 2 studies $^{33,36}$ indicate that ambulating individuals-who present the highest initial gait deficits, as indicated by a lower speed and resistance of the initial gait-present greater potential for 
Table 1 Methodological Quality and Outcomes Related to the Domains of ICF

\begin{tabular}{|c|c|c|c|c|}
\hline \multirow[b]{2}{*}{ Grade } & \multirow[b]{2}{*}{ Study } & \multicolumn{3}{|c|}{ Outcomes (ICF) } \\
\hline & & Structures and body functions & Activity & Participation \\
\hline \multicolumn{5}{|c|}{ Aerobic training } \\
\hline Very low & Tawashy et $\mathrm{a}^{20}$ & $\mathrm{X}$ & & \\
\hline Low & Silva et $\mathrm{al}^{21}$ & $\mathrm{X}$ & & \\
\hline Low & Vasiliadis et $\mathrm{al}^{22}$ & $\mathrm{X}$ & & \\
\hline Moderate & Brurok et $\mathrm{al}^{23}$ & $\mathrm{X}$ & & \\
\hline Moderate & Rosety-Rodriguez et $\mathrm{al}^{24}$ & $\mathrm{X}$ & & \\
\hline \multicolumn{5}{|c|}{ Resistance training } \\
\hline Low & Jayaraman et $\mathrm{al}^{25}$ & $\mathrm{X}$ & $\mathrm{X}$ & \\
\hline High & Harvey et $\mathrm{al}^{26}$ & $\mathrm{X}$ & & \\
\hline \multicolumn{5}{|c|}{ Balance training } \\
\hline Low & Sayenko et al ${ }^{27}$ & $\mathrm{X}$ & $\mathrm{X}$ & \\
\hline High & Boswell-Ruys et $\mathrm{al}^{28}$ & $\mathrm{X}$ & $\mathrm{X}$ & \\
\hline \multicolumn{5}{|l|}{ Gait training } \\
\hline Low & Postans et $\mathrm{al}^{29}$ & $\mathrm{X}$ & & \\
\hline Low & Thrasher et $\mathrm{al}^{30}$ & $\mathrm{X}$ & $\mathrm{X}$ & \\
\hline Low & Schwartz et $\mathrm{al}^{31}$ & & $\mathrm{X}$ & \\
\hline Low & Benito-Penalva et $\mathrm{al}^{32}$ & & $\mathrm{X}$ & \\
\hline Low & Fleerkotte et $\mathrm{al}^{33}$ & $\mathrm{X}$ & $\mathrm{X}$ & \\
\hline Low & Sharif et $\mathrm{al}^{34}$ & & $\mathrm{X}$ & \\
\hline Moderate & Labruyère and Van Hedel ${ }^{35}$ & $\mathrm{X}$ & $\mathrm{X}$ & \\
\hline Moderate & Mirbagheri et $\mathrm{al}^{36}$ & $\mathrm{X}$ & & \\
\hline High & Nooijen et $\mathrm{al}^{37}$ & & $\mathrm{X}$ & \\
\hline High & Giangregorio et $\mathrm{al}^{38}$ & $\mathrm{X}$ & & \\
\hline High & Kapadia et $\mathrm{al}^{39}$ & $\mathrm{X}$ & $\mathrm{X}$ & \\
\hline High & Lam et $\mathrm{al}^{40}$ & & $\mathrm{X}$ & \\
\hline \multicolumn{5}{|c|}{ Combined exercises } \\
\hline Low & Bizzarini et $\mathrm{al}^{41}$ & $\mathrm{X}$ & & \\
\hline Moderate & Ginis et $\mathrm{al}^{42}$ & $\mathrm{X}$ & & $\mathrm{X}$ \\
\hline Moderate & Hicks et $\mathrm{al}^{43}$ & $\mathrm{X}$ & & $\mathrm{X}$ \\
\hline High & $\begin{array}{c}\text { Totosy de } \\
\text { Zepetnek et } \mathrm{al}^{44}\end{array}$ & $\mathrm{X}$ & & \\
\hline
\end{tabular}

Abbreviation: ICF, International Classification of Functioning, Disability and Health.

improvement from the interventions. Interventions that focused on balance training included individuals with tetraplegia and paraplegia with incomplete SCI (classified ASIA Impairment Scale C-D).

Regarding the time of injury, it was observed that the studies include individuals in the chronic stage of SCI. This may happen possibly because they tend to present a stable picture in terms of clinical aspects, functional recovery as well as secondary problems. Besides choosing chronic patients, the spontaneous recovery process does not affect the end results because this mechanism occurs only in the acute and subacute phase of injury. Therefore, only 2 studies $^{29,31}$ involved gait training used in individuals in the acute and subacute phases.

\section{Methodology and Effects of Interventions}

In aerobic exercise, the main outcomes observed were improvement in the endurance of the ventilatory musculature, increase in cardiorespiratory fitness, and its influence on the sex hormone levels of individuals with SCI. The findings indicate that aerobic exercises performed in cycle ergometers, at times associated with FES are a safe strategy for individuals who have a complete injury. Exercise intensity can be controlled through heart rate measurement, however, in individuals with injury above the sixth thoracic level it is essential to use subjective scales, such as the Borg, since these individuals have an impaired cardiovascular response due to loss of sympathetic innervations. ${ }^{45}$

Regarding resistance training, according to Table 3, exercise intensity was based on percent of 1 maximal repetition (65\% RM) and on specific ranges of maximal repetitions, in this case, 10 maximal repetitions. In addition, both studies report a progression of intensity throughout the intervention. Only the study of Harvey et $\mathrm{al}^{26}$ reports the frequency of training, which was 3 times a week. Duration of each session was not reported in any study. The proposed interventions resulted in increased isometric and dynamic muscle strength of the lower limbs in individuals with incomplete SCI who had some degree of voluntary control. One of the authors 
Table 2 Methodological Quality and Aerobic Exercises

\begin{tabular}{|c|c|c|c|c|c|c|}
\hline Grade & Study & $\begin{array}{l}\text { Subject } \\
\text { description }\end{array}$ & Objective & $\begin{array}{l}\text { Intervention } \\
\text { time }\end{array}$ & FITT principles & Effects of intervention \\
\hline Very low & $\begin{array}{l}\text { Tawashy } \\
\text { et al }{ }^{20}\end{array}$ & $\begin{array}{l}\mathrm{N}=1 \text { subject } \\
\text { SCI level: } \mathrm{C} 5-\mathrm{C} 6 \\
\text { AIS A }\end{array}$ & $\begin{array}{l}\text { Presenting the process of } \\
\text { prescribing aerobic exer- } \\
\text { cise during the initial } \\
\text { rehabilitation of an indi- } \\
\text { vidual who suffered cer- } \\
\text { vical SCI. }\end{array}$ & $8 \mathrm{wk}$ & $\begin{array}{l}\text { F: } 3 \times \text { per week } \\
\text { I: } 50 \%-80 \% \text { HRR } \\
\text { and RPE } 12-18 \\
\text { Borg Scale } \\
\text { T: aerobic training } \\
\text { T: } 30 \text { min }\end{array}$ & $\begin{array}{l}\text { Improved exercise tolerance. } \\
\text { Increase in peak oxygen con- } \\
\text { sumption }(20 \%) \text {. } \\
\text { Improves orthostatic tolerance. } \\
\text { Psychological benefits reported } \\
\text { by the individual. }\end{array}$ \\
\hline Low & Silva et $\mathrm{al}^{21}$ & $\begin{array}{l}\mathrm{N}=12 \text { subjects } \\
\text { SCI level: } \mathrm{T} 1-\mathrm{T} 12 \\
\text { AIS A }\end{array}$ & $\begin{array}{l}\text { Compare VME of indivi- } \\
\text { duals without SCI to indi- } \\
\text { viduals with complete SCI } \\
\text { and to evaluate the effect of } \\
\text { an aerobic training pro- } \\
\text { gram on muscular endur- } \\
\text { ance respiratory muscle. }\end{array}$ & $6 \mathrm{wk}$ & $\begin{array}{l}\text { F: } 3 \times \text { per week } \\
\text { I: HR correspond- } \\
\text { ing to the anaerobic } \\
\text { threshold } \\
\mathrm{T}: \text { aerobic training } \\
\mathrm{T}: 30 \mathrm{~min}\end{array}$ & $\begin{array}{l}\text { Improvement in FVC and } \\
\text { respiratory muscle endurance. } \\
70 \% \text { increase in test time. } \\
70 \% \text { increase in MVV). }\end{array}$ \\
\hline Low & $\begin{array}{l}\text { Vasiliadis } \\
\text { et } \mathrm{al}^{22}\end{array}$ & $\begin{array}{l}\mathrm{N}=8 \text { subjects } \\
\text { SCI level: T6-T12 } \\
\text { AIS A }\end{array}$ & $\begin{array}{l}\text { To evaluate the response of } \\
\text { angiogenic molecules in } \\
\text { individuals with SCI and } \\
\text { without injury during an } \\
\text { exercise session performed } \\
\text { on a cycle ergometer for } \\
\text { upper limbs. }\end{array}$ & $2 \mathrm{~d}$ & $\begin{array}{l}\mathrm{F}: \mathrm{NM} \\
\mathrm{I}: 60 \% \mathrm{VO}_{2} \max \\
\text { T: aerobic training } \\
\text { T: NM }\end{array}$ & $\begin{array}{l}\text { Acute increase in the concen- } \\
\text { tration of angiogenic molecules } \\
\text { in individuals with and without } \\
\text { SCI. }\end{array}$ \\
\hline Moderate & $\begin{array}{l}\text { Brurok } \\
\text { et } \mathrm{al}^{23}\end{array}$ & $\begin{array}{l}\mathrm{N}=6 \text { subjects } \\
\text { SCI level: C7-T5 } \\
\text { AIS A }\end{array}$ & $\begin{array}{l}\text { To evaluate the effect of } \\
\text { high-intensity and interval } \\
\text { program training per- } \\
\text { formed with upper body } \\
\text { cycle ergometer and } \\
\text { ergometer assisted by } \\
\text { functional electrical stim- } \\
\text { ulation on the stroke vol- } \\
\text { ume and peak oxygen } \\
\text { consumption peak for in- } \\
\text { dividuals with SCI. }\end{array}$ & $8 \mathrm{wk}$ & $\begin{array}{l}\text { F: } 3 \times \text { per week } \\
\text { I: } 85 \%-95 \% \text { peak } \\
\text { work capacity } \\
\text { T: aerobic training } \\
\text { T: NM }\end{array}$ & $\begin{array}{l}\text { Increased peak systolic volume } \\
(33 \%) \text {, increased HR }(27.7 \%) \text {, } \\
\text { significant increase in peak } \\
\text { oxygen consumption }(25.3 \%) \text {, } \\
\text { compared with the control } \\
\text { group. }\end{array}$ \\
\hline Moderate & $\begin{array}{l}\text { Rosety- } \\
\text { Rodriguez } \\
\text { et } \mathrm{al}^{24}\end{array}$ & $\begin{array}{l}\mathrm{N}=17 \text { subjects } \\
\text { SCI level: } \mathrm{T} 4 \text { or } \\
\text { below } \\
\text { EG: } 9 \text { subjects } \\
\text { CG: } 8 \text { subjects }\end{array}$ & $\begin{array}{l}\text { Check the influence of an } \\
\text { exercise program in man- } \\
\text { ual cycle ergometer, the } \\
\text { level of sex hormones, the } \\
\text { effects on muscle strength } \\
\text { and body composition of } \\
\text { individuals with chronic } \\
\text { SCI. }\end{array}$ & $12 \mathrm{wk}$ & $\begin{array}{l}\text { F: } 3 \times \text { per week } \\
\text { I: } 50 \%-65 \% \text { HRR } \\
\text { T: aerobic training } \\
\text { T: } 30-45 \text { min }\end{array}$ & $\begin{array}{l}\text { Significant increase in circulat- } \\
\text { ing testosterone levels. } \\
\text { No difference in LH and FSH } \\
\text { levels. } \\
\text { Increased isometric force esti- } \\
\text { mated at hand dynamometer. } \\
\text { Decrease in waist } \\
\text { circumference. }\end{array}$ \\
\hline
\end{tabular}

Abbreviations: AIS, ASIA Impairment Scale; CG, control group; EG, experimental group; FITT, frequency, intensity, type, and time; FSH, follicle-stimulating hormone; FVC, forced vital capacity; HRR, heart rate reserve; LH, luteinizing hormone; MVV, maximum voluntary ventilation; NM, not mentioned; RPE, ratings of perceived exertion; SCI, spinal cord injury; VME, ventilatory muscle endurance.

found an improvement on balance capacity after the intervention, even not providing specific balance training, which suggests that lack of muscle strength influences balance deficit.

On the other hand, the interventions based on balance training, as described in Table 4, present a frequency of 3 times a week, and only one of the studies ${ }^{27}$ reports a duration of 60 minutes per session. Taken together, these results indicate that interventions focused specifically on balance training are effective. The study that performed the intervention in the sitting position resulted in improvement to sit without assistance, and the one that performed the intervention using standing balance training with visual feedback (VBT) showed improvements in dynamic and static balance. However, it is not possible to establish the parameters for its prescription due to the low number of included studies. Progressively complex exercises can be adapted to the specific tasks and this may influence to develop and maintain independence, such as transfers from sitting to standing and maintaining sitting posture.
All studies that used gait training were performed in association with other devices, such as FES, electromechanical tools (such as robotic exoskeletons), and treadmills with partial weight support. The duration of the sessions ranges from 45 to 60 minutes, with a frequency of 2 to 5 times a week. Only one study ${ }^{30}$ presented the intensity of the training, which was based on the percent of the maximum velocity ( $120 \%$ of the initial auto selected gait velocity) of each individual. The results observed with gait training were consistent. In general, interventions resulted in increased speed, endurance (the total distance walked in $6 \mathrm{~min}$ ), ${ }^{29}$ and gait control. The parameters used for progression of the training overload involved modifications in the percentage of the body weight supported, the speed of the treadmill, and the duration of the exercise.

In one study, ${ }^{39}$ no difference was observed between a specific gait training program and a training program which combined aerobic exercises and resistance training in relation to improvement of gait and balance of participants. These results may indicate that 
Table 3 Methodological Quality and Resistance Training

\begin{tabular}{|c|c|c|c|c|c|c|}
\hline Grade & Study & $\begin{array}{l}\text { Subject } \\
\text { description }\end{array}$ & Objective & $\begin{array}{l}\text { Intervention } \\
\text { time }\end{array}$ & FITT principles & Effects of intervention \\
\hline Low & $\begin{array}{l}\text { Jayaraman } \\
\text { et }^{25}{ }^{25}\end{array}$ & $\begin{array}{l}\mathrm{N}=5 \text { subjects } \\
\text { SCI level: } \mathrm{C} 2-\mathrm{T} 7 \\
4 \text { tetraplegics/1 } \\
\text { paraplegics } \\
\text { AIS C-D }\end{array}$ & $\begin{array}{l}\text { Evaluate the effects of a } 4 \text {-wk } \\
\text { high-intensity strength training } \\
\text { program using repeated maximal } \\
\text { isometric contractions in func- } \\
\text { tionality and strength of the lower } \\
\text { limbs in individuals with incom- } \\
\text { plete SCI, comparing it to a } \\
\text { conventional force training } \\
\text { program. }\end{array}$ & $4 \mathrm{wk}$ & $\begin{array}{c}\text { F: NM } \\
\text { I: maximal isomet- } \\
\text { ric contraction } \\
50 \%-65 \% \mathrm{MR} \\
\text { T: strength training } \\
\text { T: NM }\end{array}$ & $\begin{array}{l}\text { Significant increase in } \\
\text { distance traveled (6MWT). } \\
\text { Improving balance (Berg } \\
\text { Balance Scale). } \\
\text { Increased maximum iso- } \\
\text { metric strength of the } \\
\text { muscle groups of the lower } \\
\text { limbs. }\end{array}$ \\
\hline High & $\begin{array}{l}\text { Harvey } \\
\text { et }^{2} \mathrm{l}^{26}\end{array}$ & $\begin{array}{l}\mathrm{N}=20 \text { subjects } \\
\text { EG: } 10 \text { subjects } \\
\text { CG: } 10 \text { subjects } \\
\text { (without interven- } \\
\text { tion) } \\
\text { SCI level: C5-L2 } \\
\text { AIS C-D }\end{array}$ & $\begin{array}{l}\text { To determine the effectiveness of } \\
\text { progressive strength training } \\
\text { program assisted by functional } \\
\text { electrical stimulation }(\mathrm{EF}) \text { to } \\
\text { increase muscle strength of the } \\
\text { quadriceps of individuals with } \\
\text { SCI. }\end{array}$ & $8 \mathrm{wk}$ & $\begin{array}{c}\text { F: } 3 \times \text { per week } \\
\text { I: } 12 \times \text { of } 10 \mathrm{MR} \\
\text { T: strength training } \\
\text { T: NM }\end{array}$ & $\begin{array}{l}\text { Increased voluntary quad- } \\
\text { riceps muscle strength, } \\
\text { however, it is unclear } \\
\text { whether this improvement } \\
\text { promotes significant clini- } \\
\text { cal benefits. }\end{array}$ \\
\hline
\end{tabular}

Abbreviations: AIS, ASIA Impairment Scale; CG, control group; EG, experimental group; FITT, frequency, intensity, type, and time; 6MWT, 6-min walk test; MR, maximal repetition; NM, not mentioned; SCI, spinal cord injury.

Table 4 Methodological Quality and Balance Training

\begin{tabular}{|c|c|c|c|c|c|c|}
\hline Grade & Study & $\begin{array}{l}\text { Subject } \\
\text { description }\end{array}$ & Objective & $\begin{array}{l}\text { Intervention } \\
\text { time }\end{array}$ & FITT principles & Effects of intervention \\
\hline Low & $\begin{array}{l}\text { Sayenko } \\
\text { et } \mathrm{al}^{27}\end{array}$ & $\begin{array}{l}\mathrm{N}=6 \text { subjects } \\
\mathrm{SCI} \text { level: } \mathrm{C} 4-\mathrm{T} 12 \\
2 \text { tetraplegics } 4 \\
\text { paraplegics } \\
\text { AIS C-D }\end{array}$ & $\begin{array}{l}\text { Evaluate the potential for learning } \\
\text { and performance improvement in the } \\
\text { balance using standing balance } \\
\text { training with visual feedback (VBT) } \\
\text { in individuals with incomplete SCI } \\
\text { and determine whether the balance in } \\
\text { the standing position and the } \\
\text { dynamic stability while performing } \\
\text { tasks not related to training can be } \\
\text { improved after use of VBT. }\end{array}$ & $4 \mathrm{wk}$ & $\begin{array}{l}\text { F: } 3 \times \text { per week } \\
\text { I: NM } \\
\text { T: balance training } \\
\text { T: } 60 \text { min }\end{array}$ & $\begin{array}{l}\text { Improved performance of the } \\
\text { participants to the different } \\
\text { referred games. } \\
\text { Improved static and dynamic } \\
\text { postural stability. }\end{array}$ \\
\hline High & $\begin{array}{c}\text { Boswell- } \\
\text { Ruys et al }\end{array}$ & $\begin{array}{l}\mathrm{N}=30 \text { subjects } \\
\text { EG: } 15 \text { subjects } \\
\text { CG: } 15 \text { subjects } \\
\text { SCI level: } \text { T1-T12 }\end{array}$ & $\begin{array}{l}\text { To determine the effectiveness of a } \\
\text { training program using a specific task } \\
\text { to improve the ability to sit without } \\
\text { support individuals with SCI. }\end{array}$ & $6 \mathrm{wk}$ & $\begin{array}{l}\text { F: } 3 \times \text { per week } \\
\text { I: NM } \\
\text { T: balance training } \\
\text { T: NM }\end{array}$ & $\begin{array}{l}\text { Improved ability to remain } \\
\text { seated without support in } \\
\text { individuals with SCI, as } \\
\text { assessed by: maximum } \\
\text { amplitude balance of the test } \\
\text { (maximal balance range) and } \\
\text { trunk oscillation test (upper- } \\
\text { body sway full length). }\end{array}$ \\
\hline
\end{tabular}

Abbreviations: AIS, ASIA Impairment Scale; CG, control group; EG, experimental group; FITT, frequency, intensity, type, and time; NM, not mentioned; SCI, spinal cord injury.

lack of muscle strength is a limiting factor for gait functionality in these individuals. Three of the included studies that involved gait training $29,34,40$ found a transfer of the benefits obtained with the interventions using FES or electromechanical devices for overground gait.

Studies with combined interventions, which include 2 or more types of training in the same program, have used from ergometers to resistance exercises with cables and machines. The main measures to control the intensity of aerobic training were based on percent of maximum heart rate $(70 \%-80 \% \mathrm{HRmax})$ and subjective effort perception (measured as 3-6 on a modified Borg Scale). The weekly frequency of the programs ranged from 2 to 5 sessions and the duration ranged from 45 to 120 minutes per session. ${ }^{41-44}$

In addition to the observed benefits such as increase in muscle strength, work capacity, and improvement of body composition, such as visceral fat reduction, the interventions also resulted in benefits in the quality of life, for example, stress reduction, decrease in perception of pain and depression, and an increase in physical self-concept, which is fundamental since the injury has a negative impact on the participation level. ${ }^{46} \mathrm{~A}$ striking fact of the great majority of studies is the lack of training parameters for the progression of the intensity and volume, which may limit the benefits of the proposed exercises.

\section{Quality of Studies and Outcomes According to ICF}

Our results suggest that there is more evidence available for gait training, with more methodological rigor comparing to other types of exercise. In addition, a large volume of research involves gait training in SCI, probably because this is the main priority of this population as related in previous studies. ${ }^{47,48}$ 


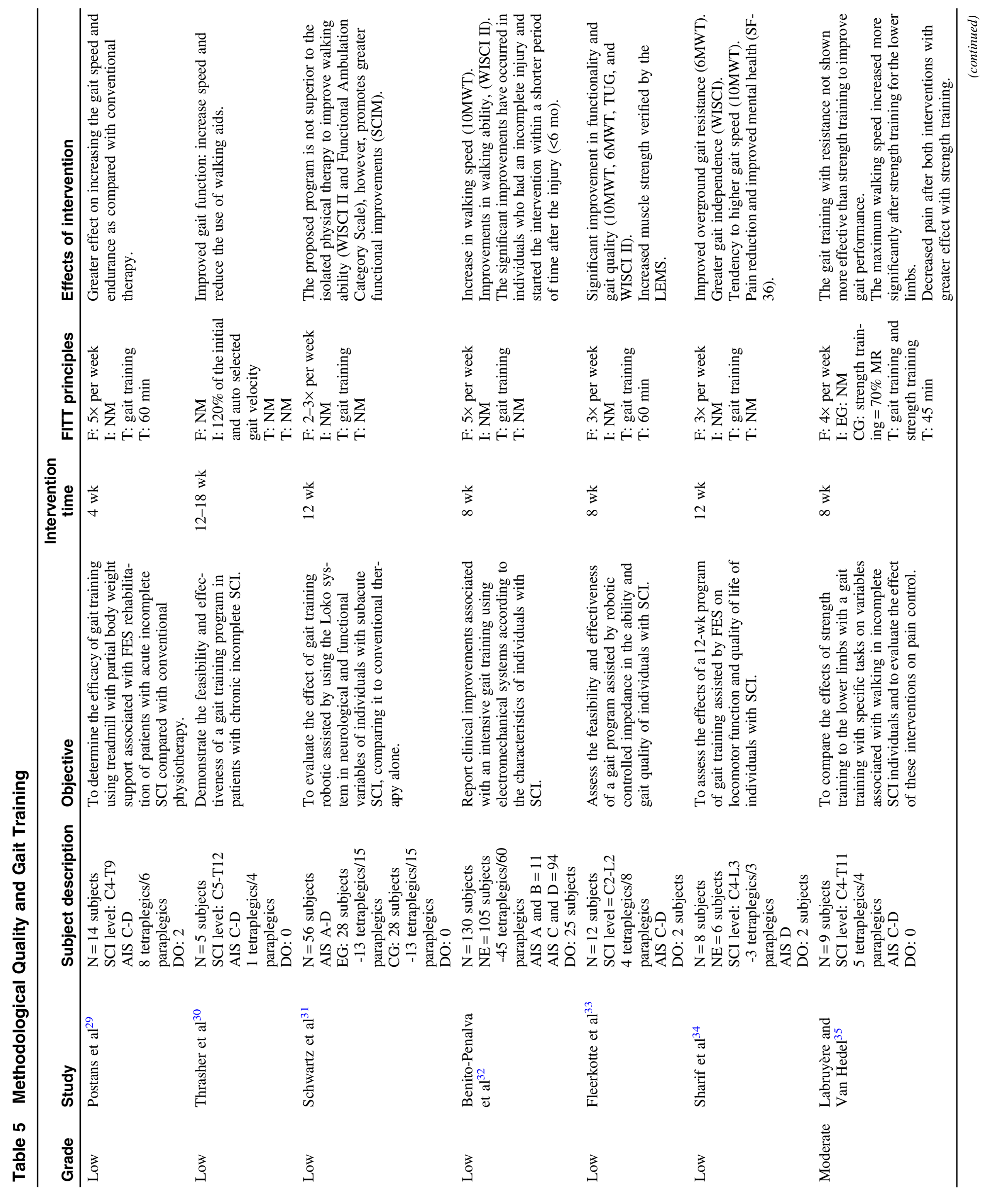




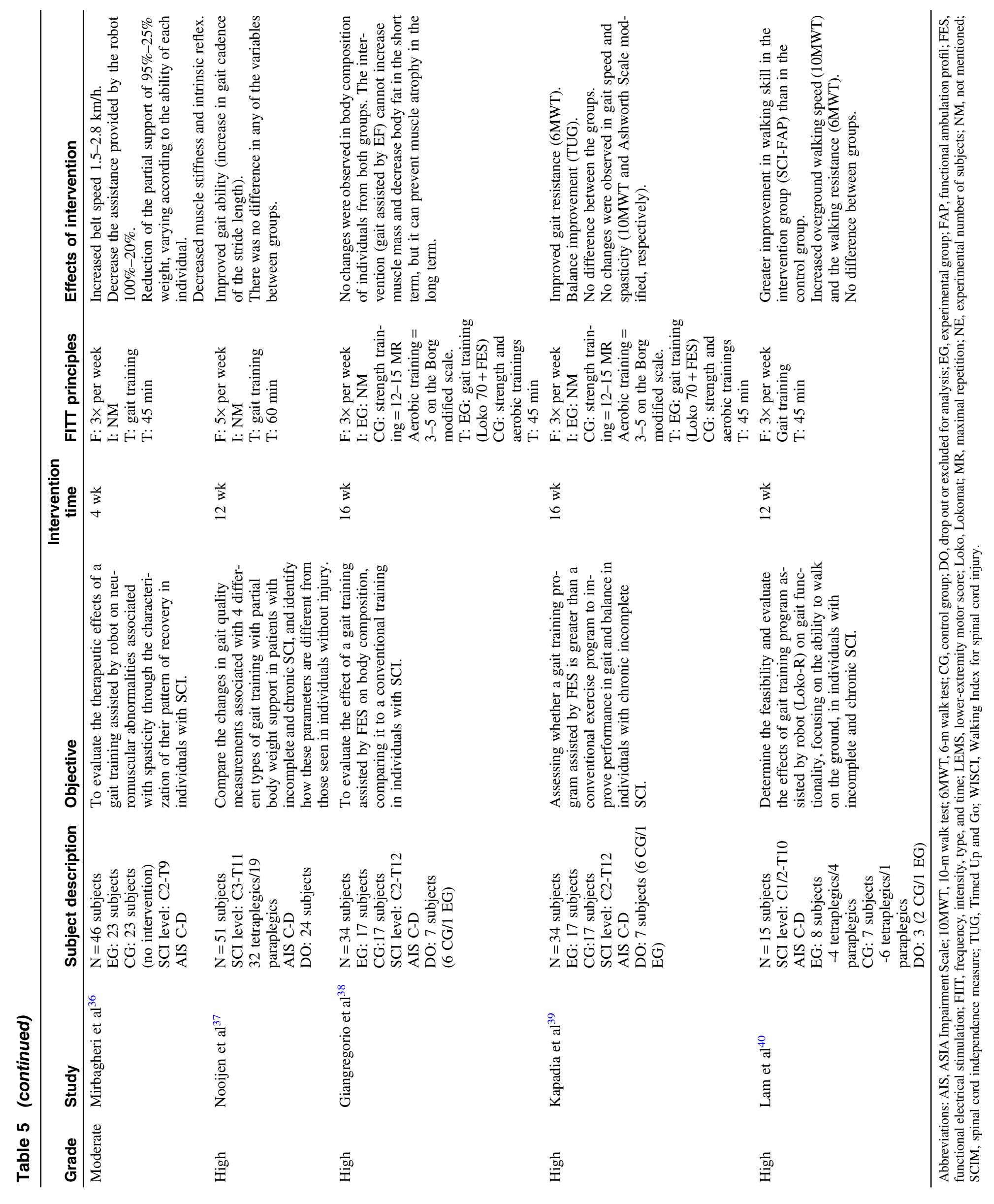


Table 6 Methodological Quality and Combined Exercises

\begin{tabular}{|c|c|c|c|c|c|c|}
\hline Grade & Study & $\begin{array}{l}\text { Subject } \\
\text { description }\end{array}$ & Objective & $\begin{array}{c}\text { Intervention } \\
\text { time }\end{array}$ & FITT principles & Effects of intervention \\
\hline Low & $\begin{array}{l}\text { Bizzarini } \\
\text { et } \mathrm{al}^{41}\end{array}$ & $\begin{array}{l}\mathrm{N}=21 \text { subjects } \\
\text { SCI level: } \mathrm{C} 4-\mathrm{L} 2 \\
6 \text { tetraplegics } / 15 \\
\text { paraplegics } \\
\text { AIS B-C }\end{array}$ & $\begin{array}{l}\text { To evaluate the effects of a } \\
\text { rehabilitation program } \\
\text { training with ergometers in } \\
\text { subacute SCI individuals. }\end{array}$ & $6 \mathrm{wk}$ & $\begin{array}{l}\text { F: } 5 \times \text { per week } \\
\text { I: aerobic training } \\
70 \%-80 \% \text { of maxi- } \\
\text { mum HR. } \\
\text { Strength training } \\
40 \%-60 \% \text { MR } \\
\text { T: aerobic training and } \\
\text { strength training for } \\
\text { upper limbs } \\
\text { T: } 90 \text { min }\end{array}$ & $\begin{array}{l}\text { Increase of the work } \\
\text { capacity during the erg- } \\
\text { ometers exercises in the } \\
\text { first } 4 \text { wk. } \\
\text { There was no statistical } \\
\text { difference between the } \\
\text { corporal body weight by } \\
\text { the begging and the end of } \\
\text { the intervention. } \\
\text { The body fat percentual } \\
\text { remained the same, except } \\
\text { in male individuals with } \\
\text { low level of injury } \\
\text { (paraplegia). } \\
\text { Hematologics alterations } \\
\text { were not observed. }\end{array}$ \\
\hline Moderate & Ginis et $\mathrm{al}^{42}$ & $\begin{array}{l}\mathrm{N}=34 \text { subjects } \\
\text { EG: } 21 \text { Subjects } \\
\text { CG: } 13 \text { subjects } \\
\text { SCI level: NM } \\
\text { AIS: complete and } \\
\text { incomplete } \\
\text { DO: } 4 \text { (2 EG, } 2 \text { CG) }\end{array}$ & $\begin{array}{l}\text { Evaluate whether exercise } \\
\text { can be used as a strategy } \\
\text { for the reduction of pain } \\
\text { and improvement of sub- } \\
\text { jective perception of well- } \\
\text { being of individuals with } \\
\text { SCI. }\end{array}$ & $12 \mathrm{wk}$ & $\begin{array}{l}\text { F: } 2 \times \text { per week } \\
\text { I: aerobic training }= \\
70 \% \text { of maximum } \\
\text { capacity. } \\
\text { T: aerobic and strength } \\
\text { training } \\
\text { T: } 65-95 \text { min }\end{array}$ & $\begin{array}{l}\text { Stress and pain perception } \\
\text { reduction of individuals } \\
\text { with SCI. } \\
\text { Improved quality of life, } \\
\text { greater satisfaction with } \\
\text { the appearance and physi- } \\
\text { cal capacity, and } \\
\text { improvement of depres- } \\
\text { sion frame. }\end{array}$ \\
\hline Moderate & Hicks et $\mathrm{al}^{43}$ & $\begin{array}{l}\mathrm{N}=34 \text { subjects } \\
\text { EG: } 21 \text { subjects } \\
\text { CG: } 13 \text { subjects } \\
\text { SCI level: C4-L1 } \\
\text { AIS A-D } \\
\text { DO: } 11(10 \text { EG/11 } \\
\text { CG) }\end{array}$ & $\begin{array}{l}\text { Evaluate the effects of a } \\
\text { program of 9-mo exercise } \\
\text { on strength, performance } \\
\text { in manual cycle ergometer, } \\
\text { psychological variables, } \\
\text { and quality of life. }\end{array}$ & $36 \mathrm{wk}$ & $\begin{array}{l}\text { F: } 2 \times \text { per week } \\
\text { I: aerobic training }= \\
70 \% \text { of maximum HR } \\
\text { or } 3-4 \text { in the adapted } \\
\text { scale of Borg. } \\
\text { Strength training }=50- \\
80 \% \text { MR } \\
\text { T: strength and aerobic } \\
\text { training } \\
\text { T: } 90-120 \text { min }\end{array}$ & $\begin{array}{l}\text { Increased muscle strength. } \\
\text { Improved performance in } \\
\text { manual cycle ergometer. } \\
\text { Improved quality of life } \\
\text { and psychological well- } \\
\text { being (decreased pain, } \\
\text { depression, and stress } \\
\text { self-reported). }\end{array}$ \\
\hline High & $\begin{array}{l}\text { Totosy de } \\
\text { Zepetnek } \\
\text { et } \mathrm{al}^{44}\end{array}$ & $\begin{array}{l}\mathrm{N}=23 \text { subjects } \\
\text { EG: } 12 \text { subjects } \\
\text { CG: } 11 \text { subjects } \\
\text { SCI level: C3-T11 } \\
\text { AIS A-C } \\
\text { DO: } 6 \text { subjects }\end{array}$ & $\begin{array}{l}\text { To assess the effects of a } \\
\text { physical exercise program } \\
\text { following the physical } \\
\text { activity guidelines for } \\
\text { adults with SCI for } 16 \mathrm{wk} \text {. }\end{array}$ & $16 \mathrm{wk}$ & $\begin{array}{l}\text { F: } 2 \times \text { per week } \\
\text { I: aerobic training }=3- \\
6 \text { in the adapted scale of } \\
\text { Borg. } \\
\text { Strength training }= \\
50 \%-70 \% \text { MR } \\
\text { T: aerobic and strength } \\
\text { training } \\
\text { T: } 60 \text { min } \\
\text { ( } 20 \text { min minimum for } \\
\text { aerobic training) }\end{array}$ & $\begin{array}{l}\text { Improvement in parame- } \\
\text { ters of body composition } \\
\text { (decreased visceral fat). } \\
\text { Improvement in carotid } \\
\text { artery distensibility. } \\
\text { There was no change in } \\
\text { blood markers of cardio- } \\
\text { vascular risk (ie, in the } \\
\text { fasting insulin level). }\end{array}$ \\
\hline
\end{tabular}

Abbreviations: AIS, ASIA Impairment Scale; CG, control group; DO, drop out or excluded for analysis; EG, experimental group; FIIT, frequency, intensity, type, and time; $\mathrm{HR}$, heart rate; MR, maximal repetition; NM, not mentioned; SCI, spinal cord injury.

Regarding the characteristics of the interventions, the FITT principles are described in more detail within the gait training studies. It is observed the weekly frequency was mostly 3 times a week, and the variables used to modulate the intensity were primarily the speed of the treadmill and the percent of partial weight support. The duration of trainings ranged from 45 to 60 minutes. The studies of Kapadia et $\mathrm{al}^{39}$ and Sharif et $\mathrm{al}^{34}$ used protocols with very similar FITT characteristics. Both observed improvement in gait endurance, assessed by the 6minute walk test, whereas, in the study by Sharif et al, ${ }^{34}$ there was a tendency to increase gait speed, which was not verified by Kapadia et al. ${ }^{39}$
Considering the outcomes presented according to the ICF domains, the authors who propose combined interventions (aerobic exercise and resistance training) are more concerned with outcomes in terms of body structures and functions. Totosy de Zepetnek et al ${ }^{44}$ evaluated the effect of a 16-week program combining aerobic exercise with resistance training - following the guidelines for physical exercise prescription for adults with SCI - and verified positive effects on some parameters of body composition and distensibility of the carotid artery. However, there was no improvement in several parameters associated with increased cardiovascular risk. ${ }^{49}$

The main outcomes evaluated the body structures and functions that ranged from general and specific muscle strength to 
lower-extremity motor score (the sum of the score for muscular strength of the 10 muscles of the lower limb), physical capacities (vital capacities, peak oxygen consumption, cardiac output, maximum voluntary ventilation, etc.), anthropometric measures (body composition, weight, percentage of fat, and waist circumference), and cardiovascular and hormonal markers.

Activity is defined as the execution of a task or action by an individual. Participation is understood as "involvement in life situations" and is considered a key component of human functioning, as described in the ICF. ${ }^{50}$ Although most of the objectives of people with SCI are in the areas of activity and participation, the studies of this review focused on outcomes of structures and functions.

A few studies have associated activity outcomes, such as general tests of gait performance (10-meter walk, 6-min walk test, Timed Up and Go), specific tests for populations with SCI; Walking Index for SCI and Functional Ambulation Category Scale, general balance tests (Berg Scale, maximal balance range, and upper-body sway total length), and specific tests of functional independence (SCIM III).

In general, studies with gait and balance training present outcomes targeted to the scope of activities, with the exception of one study of resistance training, ${ }^{25}$ whose authors assessed outcomes related to gait (6-min walk test) and balance (Berg test).

In the study of Boswell-Ruyset et al, ${ }^{28}$ after an intervention based on balance training with specific tasks, there was an improvement in the ability to sit without support. The authors reported benefits for the accomplishment of a series of daily life activities independently, such as dressing and feeding, resulting in less activity limitations.

Of the 12 studies that assessed outcome of activity, 9 were studies of gait training. This shows a greater relation between this type of exercise program and activity outcomes. Only 2 studies assessed aspects of participation. Both studies evaluated combined exercise program and used the SF-36 scale of secondary outcome.

The SF-36 scale is a generic outcome measure reported by the patient, designed to be applied to all health conditions. Its objective is to quantify health status and measure health-related quality of life. It is considered an instrument to evaluate some aspects of participation, used in studies with this population since the subject is evaluated on some items, such as "accomplishing less than you would like and limitations in the kind of work," "accomplishing less than you would like," and "didn't do work as carefully as usual." However, it is not considered a specific scale regarding the aspects of the participation, not addressing all important aspects of this domain. ${ }^{50}$

Although there are many participatory evaluation tools conceptually based on ICF, Ruoranen et al ${ }^{51}$ express that despite apparently clear and comprehensive lists of categories, the ICF's definition of participation as "involvement in a life situation" does not specify how participation relates to other concepts, such as social integration, nor does it clarify what participation restrictions actually mean to persons with disabilities. For this reason we consider the absence of specific outcomes of participation an important limitation of the studies found.

The various choices of measures and scales of evaluation may suggest a difficult selection or even a limitation in the selection of appropriate tools for the outcomes of interest, in particular the specific tools used within the SCI population including different domains of the ICF.

In this context, Padula et $\mathrm{al}^{52}$ discuss the need to evaluate the effectiveness of intervention programs in all ICF domains, considering not only the domains of body structure and body function but also activities and social participation, and the need to use specific assessment tools for SCI.

\section{Barrier and Facilitators Related to Adherence for Physical Exercise in Individuals With SCI}

Most of the studies have a low sample size, which results in a low external validity of the findings. This fact is probably associated with the barriers to joining an intervention program and/or research protocol. For example, one of the main barriers those individuals with SCI face is mobility restrictions, especially in individuals with tetraplegia, which makes it difficult to adhere to the proposed programs.

In addition to the mobility restrictions, another limiting factor would be the high costs involved in the particular treatments, together with a possible lower financial independence of these individuals. A factor that could facilitate the adherence of this population to physical exercise programs would be a low frequency of training sessions (eg, 2 times per week) associated with home program and the increase of intensity, which taken together may not interfere in the end result.

\section{Limitations of the Study}

The main limitation of the present review is the low quality of the included studies, according to the GRADE system, which limits clinical decisions based on strong evidence. The studies presented a small sample size and very heterogeneous characteristics with respect to age and time after injury, which may affect the validity of data.

\section{Directions for Future Research}

The results of the present review highlight the need for studies with greater methodological rigor, mainly in relation to the homogeneity of the sample characteristics, since they exert a great influence on the potential of functional recovery. Sample size may also be considered, because it can compromise the external validity, limiting the generalization of the results.

In addition, precision and specificity in the parameters of the training interventions, which includes the FITT principles, are highly recommended, as well as other variables, such as the level of supervision, the environment in which the interventions were performed, and the possible adverse events that occur during the intervention, such as high blood pressure peaks associated with autonomic dysreflexia or hypotension. Such information is fundamental considering the lack of evidence on the acute responses to exercise and the greater risk during the practice of physical activity to this population.

Finally, it is of great importance that future clinical trials select tools or scales adequate to the outcomes studied, which are specific to the population with SCI and sensitive to changes after short- or long-term interventions.

\section{Conclusion}

Considering studies classified as high and moderate quality of evidence, the positive effects were observed in the body structures and functions for aerobic, resistance training and combined exercises, and gait training. In the domain of activities and 
participation, positive effects were observed for gait training, balance training, and combined interventions.

Due to the low methodological quality of most of the selected studies, as well as the variability in the outcomes-especially in studies that investigated aerobic exercise-it is difficult to establish parameters for the prescription of physical exercise programs for SCI people.

However, gait training is the modality with highest volume of publications, whereas balance training was the least frequently investigated program type. Therefore, there is a lack of controlled studies, mainly randomized clinical trials, which evaluate the potential effects of different types of physical exercises.

\section{References}

1. Hartkopp A, Brønnum-Hansen H, Seidenschnur AM, BieringSørensen F. Survival and cause of death after traumatic spinal cord injury. A long-term epidemiological survey from Denmark. Spinal Cord. 1997;35:76-85. PubMed ID: 9044513 doi:10.1038/sj. sc. 3100351

2. van den Berg-Emons RJ, Johannes BB, Janneke H, et al. A prospective study on physical activity levels after spinal cord injury during inpatient rehabilitation and the year after discharge. Arch Phys Med Rehabil. 2008;89:2094-2101. PubMed ID: 18996237 doi:10.1016/j. apmr.2008.04.024

3. Singh A, Tetreault L, Kalsi-Ryan S, Nouri A, Fehlings MG. Global prevalence and incidence of traumatic spinal cord injury. Clin Epidemiol. 2014;23:309-331.

4. Sisto S, Evans N. Activity and fitness in spinal cord injury: review and update. Curr Phys Med Rehabil Rep. 2014;2:147-157. doi:10.1007/ s40141-014-0057-y

5. Washburn RA, Figoni SF. Physical activity in chronic cardiovascular disease prevention in spinal cord injury: a comprehensive literature review. Top Spinal Cord Inj Rehabil. 1998;3:16-32.

6. Bernard PL, Mercier J, Varray A, Prefaut C. Influence of lesion level on the cardioventilatory adaptations in paraplegic wheelchair athletes during muscular exercise. Spinal Cord. 2000;38:16-25. PubMed ID: 10762193 doi:10.1038/sj.sc.3100956

7. Gorgey A, Gater D. Prevalence of obesity after spinal cord injury. Top Spinal Cord Inj Rehabil. 2007;12:1-7. PubMed ID: 29472754 doi:10. 1310/sci1204-1

8. Bauman WA, Spungen AM. Metabolic changes in persons after spinal cord injury. Phys Med Rehabil Clin N Am. 2000;11:109140. PubMed ID: 10680161 doi:10.1016/S1047-9651(18)30150-5

9. Bauman WA, Spungen AM. Carbohydrate and lipid metabolism in chronic spinal cord injury. J Spinal Cord Med. 2001;24:266-277. PubMed ID: 11944785 doi:10.1080/10790268.2001.11753584

10. Finley MA, Rodgers MM, Keyser R. Impact of physical exercise on controlling secondary conditions associated with spinal cord injury. Neurol Rep. 2002;26(1):21-31. doi:10.1097/01253086-20022601000007

11. Dunlop D, Song J, Arnston E, et al. Sedentary time in US older adults associated with disability in activities of daily living independent of physical activity. J Phys Act Health. 2015;12(1):93-101. PubMed ID: 24510000 doi:10.1123/jpah.2013-0311

12. Heath G, Fentem P. Physical activity participation among persons with disabilities - a public health perspective. Exerc Sport Sci Rev. 1997;25:195-234. PubMed ID: 9213093 doi:10.1249/00003677199700250-00010

13. Rimmer J, Riley B, Wang E, Rauworth A, Jurkowski J. Physical activity participation among persons with disabilities: barriers and facilitators. Am J Prev Med. 2004;26:419-425. PubMed ID: 15165658 doi:10.1016/j.amepre.2004.02.002

14. Harness ET, Yozbatiran N, Cramer SC. Effects of intense exercise in chronic spinal cord injury. Spinal Cord. 2008;46:733-737. PubMed ID: 18521094 doi:10.1038/sc. 2008.56

15. Ginis KA, Latimer AE, Buchholz AC, et al. Establishing evidencebased physical activity guidelines: methods for the Study of Health and Activity in People with Spinal Cord Injury (SHAPE SCI). Spinal Cord. 2008;46:216-221. doi:10.1038/sj.sc.3102103

16. Bromley I. Paraplegia e Tetraplegia: Um Guia Teórico-Prático para Fisioterapeutas, Cuidadores e Familiares. 4th ed. Rio de Janeiro, Brazil: Revinter; 1997.

17. Haas B, Playford ED, Ahmad AQ, Yildiran T, Gibbon AJ, Freeman JA. Rehabilitation goals of people with spinal cord injuries can be classified against the International Classification of Functioning, Disability and Health Core Set for spinal cord injuries. Spinal Cord. 2016;54:324-328. PubMed ID: 26345484 doi:10.1038/sc. 2015.155

18. Billinger SA, Boyne P, Coughenour E, Dunning K, Mattlage A. Does aerobic exercise and the FITT principle fit into stroke recovery? Curr Neurol Neurosci Rep. 2015;15:519. PubMed ID: 25475494 doi:10. 1007/s11910-014-0519-8

19. Ministério da Saúde. Secretaria de Ciência, Tecnologia e Insumos Estratégicos. Departamento de Ciência e Tecnologia. Diretrizes metodológicas: Sistema GRADE-manual de graduação da qualidade da evidência e força de recomendação para tomada de decisão em saúde. Brasília, Brazil: Ministério da Saúde; 2014:72.

20. Tawashy AE, Eng JJ, Krassioukov AV, Miller WC, Sproule S. Aerobic exercise during early rehabilitation for cervical spinal cord injury. Phys Ther. 2010;90:427-437. PubMed ID: 20093326 doi:10.2522/ptj.20090023

21. Silva AC, Neder JA, Chiurciu MV, et al. Effect of aerobic training on ventilatory muscle endurance of spinal cord injured men. Spinal Cord. 1998;36:240-245. PubMed ID: 9589523 doi:10.1038/sj.sc. 3100575

22. Vasiliadis AV, Zafeiridis A, Dipla K, et al. Circulating angiogenic biomolecules at rest and in response to upper-limb exercise in individuals with spinal cord injury. J Spinal Cord Med. 2014; 37:226-232. PubMed ID: 24090471 doi:10.1179/2045772313Y. 0000000141

23. Brurok B, Helgerud J, Karlsen T, Leivseth G, Hoff J. Effect of aerobic high-intensity hybrid training on stroke volume and peak oxygen consumption in men with spinal cord injury. Am J Phys Med Rehabil. 2011;90:407-414. PubMed ID: 21389841 doi:10.1097/PHM. 0b013e31820f960f

24. Rosety-Rodriguez M, Rosety I, Fornieles G,, et al. A short-term armcrank exercise program improved testosterone deficiency in adults with chronic spinal cord injury. Int Braz J Urol. 2014;40:367-372. PubMed ID: 25010302 doi:10.1590/S1677-5538.IBJU.2014.03.10

25. Jayaraman A, Thompson CK, Rymer WZ, Hornby TG. Short-term maximal-intensity resistance training increases volitional function and strength in chronic incomplete spinal cord injury: a pilot study. J Neurol Phys Ther. 2013;37:112-117. PubMed ID: 23673372 doi:10.1097/NPT.0b013e31828390a1

26. Harvey LA, Fornusek C, Bowden JL, et al. Electrical stimulation plus progressive resistance training for leg strength in spinal cord injury: a randomized controlled trial. Spinal Cord. 2010;48:570-575. PubMed ID: 20065991 doi:10.1038/sc.2009.191

27. Sayenko DG, Alekhina MI, Masani K, et al. Positive effect of balance training with visual feedback on standing balance abilities in people with incomplete spinal cord injury. Spinal Cord. 2010;48:886-893. PubMed ID: 20404833 doi:10.1038/sc.2010.41 
28. Boswell-Ruys CL, Harvey LA, Barker JJ, Ben M, Middleton JW, Lord SR. Training unsupported sitting in people with chronic spinal cord injuries: a randomized controlled trial. Spinal Cord. 2010; 48:138-143. PubMed ID: 19597520 doi:10.1038/sc.2009.88

29. Postans NJ, Hasler JP, Granat MH, Maxwell DJ. Functional electric stimulation to augment partial weight-bearing supported treadmill training for patients with acute incomplete spinal cord injury: a pilot study. Arch Phys Med Rehabil. 2004;85:604-610. PubMed ID: 15083437 doi:10.1016/j.apmr.2003.08.083

30. Thrasher T, Flett HM, Popovic MR. Gait training regimen for incomplete spinal cord injury using functional electrical stimulation. Spinal Cord. 2006;44:357-361. PubMed ID: 16249784 doi:10.1038/ sj.sc. 3101864

31. Schwartz I, Sajina A, Neeb M, Fisher I, Katz-Luerer M, Meiner Z. Locomotor training using a robotic device in patients with subacute spinal cord injury. Spinal Cord. 2011;49:1062-1067. PubMed ID: 21625239 doi:10.1038/sc.2011.59

32. Benito-Penalva J, Edwards DJ, Opisso E, et al. Gait training in human spinal cord injury using electromechanical systems: effect of device type and patient characteristics. Arch Phys Med Rehabil. 2012;93: 404-412. PubMed ID: 22209475 doi:10.1016/j.apmr.2011.08.028

33. Fleerkotte BM, Koopman B, Buurke JH, van Asseldonk EH, van der Kooij H, Rietman JS. The effect of impedance-controlled robotic gait training on walking ability and quality in individuals with chronic incomplete spinal cord injury: an explorative study. J Neuroeng Rehabil. 2014;11:26-40. doi:10.1186/1743-0003-11-26

34. Sharif H, Gammage K, Chun S, Ditor D. Effects of FES-ambulation training on locomotor function and health-related quality of life in individuals with spinal cord injury. Top Spinal Cord Inj Rehabil. 2014;20:58-69. PubMed ID: 24574823 doi:10.1310/sci2001-58

35. Labruyère R, Van Hedel HJ. Strength training versus robot-assisted gait training after incomplete spinal cord injury: a randomized pilot study in patients depending on walking assistance. J Neuroeng Rehabil. 2014;11:4-15. doi:10.1186/1743-0003-11-4

36. Mirbagheri MM, Kindig MW, Niu X. Effects of robotic-locomotor training on stretch reflex function and muscular properties in individuals with spinal cord injury. Clin Neurophysiol. 2015;126(5): 997-1006. doi:10.1016/j.clinph.2014.09.010

37. Nooijen CF, Ter Hoeve N, Field-Fote EC. Gait quality is improved by locomotor training in individuals with SCI regardless of training approach. J Neuroeng Rehabil. 2009;6:36-46. PubMed ID: 19799783 doi:10.1186/1743-0003-6-36

38. Giangregorio L, Craven C, Richards K, et al. A randomized trial of functional electrical stimulation for walking in incomplete spinal cord injury: effects on body composition. J Spinal Cord Med. 2012; 35:351-360. PubMed ID: 23031172 doi:10.1179/2045772312Y. 0000000041

39. Kapadia N, Masani K, Craven BC, et al. A randomized trial of functional electrical stimulation for walking in incomplete spinal cord injury: effects on walking competency. J Spinal Cord Med. 2014; 37:511-524. PubMed ID: 25229735 doi:10.1179/2045772314Y. 0000000263

40. Lam T, Pauhl K, Ferguson A, et al. Training with robot-applied resistance in people with motor-incomplete spinal cord injury: pilot study. J Rehabil Res Dev. 2015;52:113-130. PubMed ID: 26230667 doi:10.1682/JRRD.2014.03.0090

41. Bizzarini E, Saccavini M, Lipanje F, Magrin P, Malisan C, Zampa A. Exercise prescription in subjects with spinal cord injuries. Arch Phys Med Rehabil. 2005;86:1170-1175. PubMed ID: 15954056 doi:10. 1016/j.apmr.2004.11.014

42. Ginis KAM, Latimer AE, McKechnie K, Ditor DS, McCartney N, Hicks AL. Using exercise to enhance subjective well-being among people with spinal cord injury: the mediating influences of stress and pain. Rehabil Psychol. 2003;48:157-164. doi:10.1037/00905550.48.3.157

43. Hicks AL, Martin KA, Ditor DS, et al. Long-term exercise training in persons with spinal cord injury: effects on strength, arm ergometry performance and psychological well-being. Spinal Cord. 2003; 41:34-43. PubMed ID: 12494319 doi:10.1038/sj.sc.3101389

44. Totosy de Zepetnek JO, Pelletier CA, Hicks AL, MacDonald MJ. Following the physical activity guidelines for adults with spinal cord injury for 16 weeks does not improve vascular health: a randomized controlled trial. Arch Phys Med Rehabil. 2015; 96:1566-1575. PubMed ID: 26070976 doi:10.1016/j.apmr.2015. 05.019

45. Paulson TA, Bishop NC, Leicht CA, Goosey-Tolfrey VL. Perceived exertion as a tool to self-regulate exercise in individuals with tetraplegia. Eur J Appl Physiol. 2013;113(1):201-209. PubMed ID: 22644568 doi:10.1007/s00421-012-2426-5

46. Westgren N, Levi R. Quality of life and traumatic spinal cord injury. Arch Phys Med Rehabil. 1998;79:1433-1439. PubMed ID: 9821906 doi:10.1016/S0003-9993(98)90240-4

47. Ditunno PL, Patrick M, Stineman M, Ditunno JF. Who wants to walk? Preferences for recovery after SCI: a longitudinal and crosssectional study. Spinal Cord. 2008;46:500-506. PubMed ID: 18209742 doi:10.1038/sj.sc.3102172

48. Lapointe R, Lajoie Y, Serresse O, Barbeau H. Functional community ambulation requirements in incomplete spinal cord injured subjects. Spinal Cord. 2001;39(6):327-335. PubMed ID: 11438855 doi:10. 1038/sj.sc.3101167

49. Phillips AA, Krassioukov AV. Contemporary cardiovascular concerns after spinal cord injury: mechanisms, maladaptations, and management. J Neurotrauma. 2015;32(24):1927-1942. PubMed ID: 25962761 doi:10.1089/neu.2015.3903

50. Perenboom RJM, Chorus AMJ,Ruoranen K, Post MW, Juvalta S, Reinhardt JD. Measuring participation according to the International Classification of Functioning, Disability and Health (ICF). Disabil Rehabil. 2003;25(11-12):577-587. doi:10.1080/ 0963828031000137081

51. Ruoranen K, Post MW, Juvalta S, Reinhardt JD. Participation and integration from the perspective of persons with spinal cord injury from five European countries. J Rehabil Med. 2015;47(3):216-222. PubMed ID: 25403441 doi:10.2340/16501977-1911

52. Padula N, Costa M, Batista A, et al. Long-term effects of an intensive interventional training program based on activities for individuals with spinal cord injury: a pilot study. Physiother Theory Pract. 2015;31:568-574. PubMed ID: 26467667 doi:10.3109/09593985. 2015.1070938 